Sonja

Klemenčič

Andragoški center

Slovenije

\section{POMOČ BREZPOSELNIM PRI IZOBRAŽEVANJU} Učna pomoč brezposelnim
kot del Programa 5000

\section{PROGRAM 5000}

V Sloveniji že drugo leto poteka vladni program, imenovan Program 5000, katerega namen je v petih letih vsako leto vključiti 5.000 brezposelnih $\mathrm{v}$ enega izmed programov poklicnega ali strokovnega izobraževanja in tako izboljšati strokovno usposobljenost brezposelnih, ki bi tako postali bolj konkurečni na trgu dela.

Tudi izobraževanje ima omejene možnosti - če je gospodarstvo v recesiji, če ni novih delovnih mest, zgolj izobraževanje ne omogoěa zaposlovanja, vsekakor pa ni dvoma, to dokazujejo številne analize ukrepov na trgu delovne sile $v$ evropskih in drugih državah, da je lahko prav »dodatno izobraževanje učinkovit in dolgotrajni podporni ukrep pri zmanjševanju brezposelnosti. Na eni strani pomeni dodano znanje priložnost za zaposlovanje na novih delovnih mestih, če ima posameznik več znanja, pa se hitreje odziva spremembam tehnologije ali delovnim razmeram in se jim prilagaja, se hitreje prekvalificira, na drugi strani pa več znanja pripomore $k$ večji samozavesti posameznika, sposobnosti presoje položaja, iskanju rešitev in neodvisnosti.

Pred desetletjem, ko smo se v Sloveniji prvič srečali $\mathrm{z}$ večjo brezposelnostjo, je marsikje prevladovalo mnenje, da je mogoče problem brezposelnosti laže in hitreje reševati. Pričakovalo se je, da se bodo zadeve počasi same po sebi uredile in da bo kmalu brezposelnih le toliko, kot smo jih poznali pred gospodarskimi in političnimi spremembami v začetku 90. let. Andragogi in drugi strokovnjaki, ki se ukvarjamo $\mathrm{z}$ vprašanji trga delovne sile in izobraževanjem odraslih, smo že takrat opozarjali, da gre za globalen problem svetovne ekonomije, ki ni kratkotrajne narave, ki se ga moramo resno lotiti in ukrepati, da bi bile posledice manjše in manj boleče za posameznike ter skupnost.

Andragogi smo opozarjali, da se bodo med brezposelnimi najprej znašli najmanj izobraženi in da bo prav zanje najteže razvijati možnosti za ponovno zaposlitev, sami pa tudi ne bodo sposobni razvijati lastnih potencialov in iskati priložnosti zase. Zato je nujno, da se kot enega pomembnih ukrepov za reševanje problematike brezposelnosti uvaja izobraževanje, tistih, ki so že brezposelni, in tistih, ki jih brezposelnost šele ogroža. Na Andragoškem centru Slovenije so v tem času nastale številne študije in strokovne podlage za uvajanje tovrstnih ukrepov (Svetlik in drugi, 1993; skupina avtorjev, 1993), s tem vprašanjem pa so se ukvarjale tudi druge stroke, zlasti sociologija. Nekakšen vrhunec strokovnih razmišljanj in predlogov v zvezi s tem problemom je bil nacionalni posvet Izobraževanje brezposelnih aprila 1993 na Bledu, ko so se zbrali številni strokovnjaki, ki so predstavili zanimive analize, predloge in praktične izkušnje $z$ izobraževanjem brezposelnih. Na tem posvetu je bilo oblikovano sporočilo socialnim partnerjem, predvsem pa vladi in parlamentu, da je treba načrtneje, kakovostneje in celoviteje začrtati 
politiko izobraževanja brezposelnih kot enega izmed najpomembnejših ukrepov aktivne politike zaposlovanja.

Ta opozorila so bila sicer odmevna, vendar ne toliko, kot bi pričakovali. Izobraževanje brezposelnih je sicer že vsa leta stalnica $v$ programih zavodov za zaposlovanje, vendar je dolga leta prevladovalo mnenje, da je dovolj, če brezposelnim omogočimo krajše strokovno usposabljanje, morda še kak tečaj računalništva ali tujega jezika. Pri tem so opozorila, da taki tečaji lahko veliko pomagajo nekomu, ki že ima primerno strokovno izobrazbo, kaj malo pa tistemu, ki ima komaj osnovno šolo in nič ali zelo malo poklicnega znanja, naletela na gluha ušesa. Pa še to usposabljanje je bilo zelo odvisno od trenutnih možnosti, ni temeljilo na dolgoročnih usmeritvah in je zato iz leta $\mathrm{v}$ leto nihalo od mednarodno primerljivega obsega vključevanja brezposelnih do skorajda opustitve (Vilič-Klenovšek, 1998)

Taka stališča so bila vzrok, da so imeli brezposelni le redko možnost, da bi se vključevali $\mathrm{v}$ programe za pridobitev strokovne izobrazbe - če je ta obstajala, so je bili deležni le tisti, ki jim je do konca izobraževanja manjkal le letnik ali dva. Kar pogosto je bilo namreč stališče zaposlovalcev, da manj izobraženi niso njihov problem, temveč problem šolstva, šolstvo pa je zastopalo stališče, da je za reševanje problema brezposelnih odgovorno ministrstvo za delo oziroma zavodi za zaposlovanje. Na srečo pa so počasi strokovna opozorila le začela učinkovati, verjetno tudi zaradi analiz, da po obsegu kratkotrajno usposabljanje brezposelnih, še zlasti manj izobraženih, nima pričakovanih učinkov. Brezposelni še naprej ostajajo teže zaposljivi, če že najdejo delo, pa je to ponavadi le za kratek čas.

Tako je $\mathrm{v}$ sodelovanju Ministrstva za šolstvo in šport ter Ministrstva za delo, družino in socialne zadeve nastal že omenjeni Program 5000, ki vključuje naslednje cilje: »Dvig izobrazbene ravni brezposelnih oseb. Zmanjša- nje poklicnega strukturnega neskladja na trgu dela. Zagotoviti možnost izobraževanja za najmanj 5.000 brezposelnih oseb (Program: 1999). Prvo leto, to je $\vee$ šolskem letu $1998 / 99$, je bilo $\mathrm{v}$ ta program vključenih kar 7.932 brezposelnih, letos pa jih je vključenih že več kot 4.000. Po pričakovanjih je med njimi skoraj 60 odstotkov takih, ki nimajo nič ali le prvo oziroma drugo stopnjo strokovne izobrazbe, obiskujejo pa čez sto različnih poklicnih oziroma strokovnih programov.

Nedvomno gre za projekt, ki bo imel - če bo izpeljan po zamislih - pomembne učinke na različnih področjih: ne samo da bo pripomogel k bistveno drugačni izobrazbeni strukturi brezposelnih, temveč bo prav gotovo »popravil« tudi sedanjo dokaj neugodno izobrazbeno sliko aktivnega prebivalstva Slovenije. Vplival bo na razvoj mreže izobraževanja odraslih, programsko ponudbo in statusni položaj izobraževanja odraslih na splošno; prav gotovo pa bo vplival tudi na andragoško teorijo in prakso. Kar se zdi še

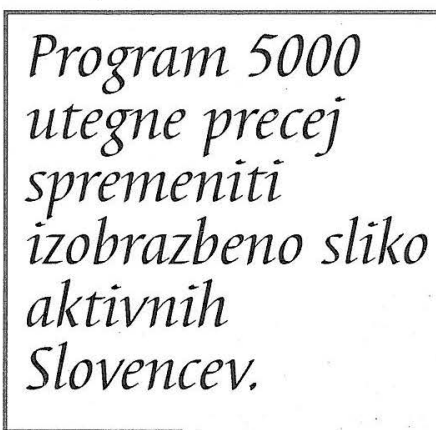
posebej pomembno, je to, da sočasno s projektom potekajo tudi evalvacijske študije, ki spremljajo posamezne ukrepe $\mathrm{v}$ projektu, da bi tako lahko sproti ugotavljali njegove učinke in odpravljali ugotovljene pomankljivosti. Formativne evalvacije so dokaj redek pojav pri uvajanju nacionalnih projektov. Vprašanj, ki jih že sproža projekt, pa je veliko: ali so brezposelni vključeni v izobraževalne programe, ki izhajajo iz potreb delodajalcev oziroma razvoja; ali je proces izobraževanja brezposelnih dovolj kakovosten; ali je smiselno toliko sredstev vlagati $v$ izobraževanje odraslih, med mladimi pa šolski osip narašča, kakšen vpliv bo imel projekt na splošno izobraževanje prebivalstva, če se bodo pretežno vsa sredstva, programska usmeritev ustanov za izobraževanje odraslih in podporni ukrepi usmerili v strokovno izobraževanje, 


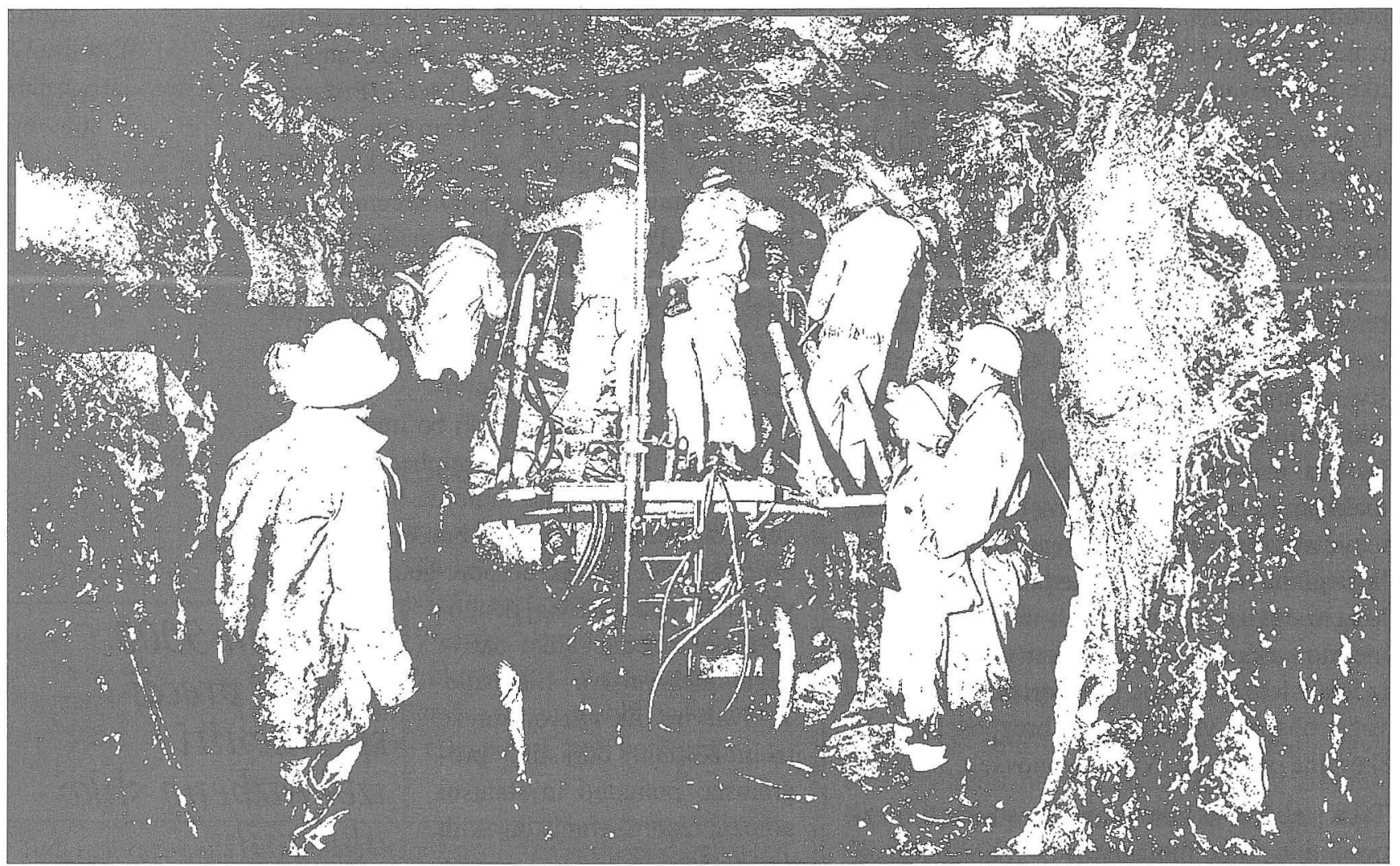

itd. Vsekakor gre za izzive, ki jih bo morala upoštevati tudi slovenska andragogika.

\section{UČNA POMOČ BREZPOSELNIM OB VKLJUČITVI V IZOBRAŽEVANJE}

Tokrat želimo razpravljati o enem izmed ukrepov, ki spremljajo Program 5000, to je o učni pomoči. Načrtovalci projekta so namreč zagotovili, da imajo načeloma vsi brezposelni možnost učne pomoči, ki naj bi jim pomagala pri odpravljanju težav ob ponovni vključitvi v izobraževanje. V prvem šolskem letu je bila učna pomoč organizirana v 20 organizacijah v različnih krajih Slovenije, pretežno v takih, ki so že prej imele razvito središče za samostojno učenje. Za to delo so bili kot mentorji praviloma izbrani brezposelni $z$ višjo ali visoko izobrazbo, ki so se za mentorstvo tudi posebej usposobili, delo pa so opravljali v okviru tako imenovanih javnih del. Izbira in usposabljanje mentorjev sta potekala novembra in decembra 1998, učna pomoč pa se je začela v začetku leta 1999.

Vsekakor gre za ukrep, ki načeloma zasluži vso pohvalo. V izobraževanju odraslih že dolgo trdimo, da je treba učečemu se različno pomagati, da bi si pridobil želeno znanje. Ne bi veliko storili, če bi brezposelne le vključili v izobraževanje, potem pa jih prepustili same sebi. Presoja, da potrebujejo dodatno pomoč, je vsekakor upravičena: velikokrat gre za odrasle, ki se že dalj časa niso izobraževali, zato potrebujejo pomoč pri obujanju pozabljenih temeljnih znanj, funkcionalno opismenjevanje, spoznavanje sodobne terminologije pri posameznih predmetih, dodatno razlago in vaje. Poleg tega pa še vse, kar je povezano z motivacijo in odpravljanjem ovir pri izobraževanju. Da bi ugotovili, kako je potekala učna pomoč, 
kakšni so njeni učinki in morebitne pomanjkljivosti, smo na Andragoškem centru Slovenije na pobudo Ministrstva za šolstvo in šport ter Zavoda RS za zaposlovanje opravili analizo, ki jo predstavljamo v nadaljevanju.*

\section{KAKO JE UČNA POMOČ ORGANIZIRANA IN KAKO POTEKA?}

Izbrani izvajalci učne pomoči so začeli delovati v začetku leta 1999. Kot navaja Zavod RS za zaposlovanje (v nadaljevanju ZRSZ) v poročilu o izpeljavi Programa 5000, je v šolskem letu 1998/99 (Program, 1999) učno pomoč uporabilo 3.015 brezposelnih. Da bi pridobili mnenja izvajalcev in uporabnikov učne pomoči o njenem poteku, smo pripravili štiri različne ankethe vprašalnike. Odločili smo se, da se bomo obrnili na vseh 20 izvajalcev učne pomoči (direktorje teh ustanov), na vseh 70 mentorjev, na vseh 43 šol (ravnatelje), ki so izobraževale brezposelne v šolskem letu 1998/99 in ki so imele $\mathrm{v}$ ta namen organizirane posebne oddelke za brezposelne, ter na 310 brezposelnih oseb, to je približno 10 odstotkov tistih, ki so bili po navedbah ZRSZ deležni učne pomoči v šolskem letu 1998/99. Novembra 1999 smo zaprosili za sodelovanje in do konca leta dobili odgovore od 17 direktorjev zavodov, ki so izvajali učno pomoč (85 odstotkov), 52 mentorjev (70 odstotkov), 25 ravnateljev srednjih šol (58 odstotkov), 191 brezposelnih (62 odstotkov), torej skupno 285 odgovorov na 443 poslanih anket (64 odstotkov). Ocenjujemo, da smo dobili zadovoljiv odstotek odgovorov, tako da je mogoče na podlagi rezultatov z dokajšnjo verjetnostjo sklepati o projektu v celoti.

\section{Število in mreža izvajalcev učne pomoči}

Organizacijsko je bila učna pomoč umeščena na 20 izobraževalnih organizacijah, ki so zagotavljale prostore, vodenje in organizacijo; od teh je bilo 15 takih, ki imajo središče za sa- mostojno učenje. Med vsemi organizacijami je bilo 13 ljudskih univerz, 5 zavodov in zasebnih organizacij za izobraževanje odraslih, en šolski center in en inštitut. Po podatkih ZRSZ je pri njih delovalo skupno 70 mentorjev.

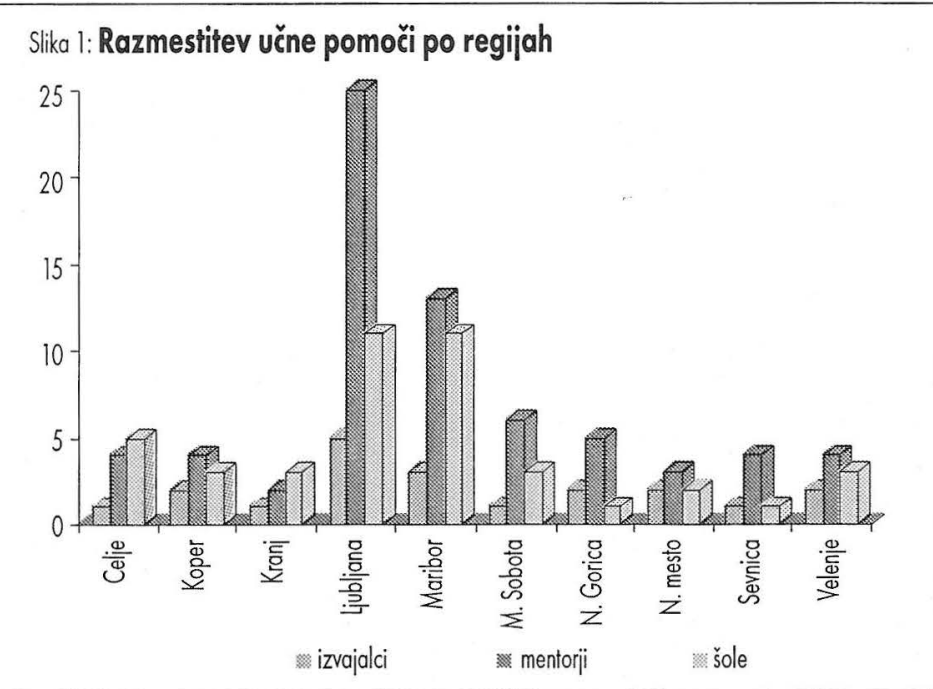

Med temeljnimi merili za število in razmestitev izvajalcev učne pomoči je bilo, kot navajata Ministrstvo za šolstvo in šport ( $v$ nadaljevanju MŠŠ) in ZRSZ, približevanje udeležencem. Pri pregledu dejanske razmestitve pa se zdi, da prevladuje načelo »pokrivanja območja delovanja posamezne organizacijske enote zavoda za zaposlovanje. Odgovor na vprašanje, ali je uresničeno načelo dostopnosti učne pomoči $\mathrm{z}$ razmestitvijo izvajalcev, je gotovo pozitiven za nekatera območja, v celoti pa ne. Še posebej zato, ker učna pomoč praviloma ni potekala na šolah, kjer so se brezposelni sicer izobraževali, niti ni bila zagotovljena v vseh krajih, kjer poteka izobraževanje. Zelo slaba je »pokritost « v celjski regiji in na Gorenjskem, razmeroma dobra je le v Ljubljani in širši okolici, ki ima na primer približno enako število šol kot mariborska regija, vendar veliko manj mentorjev. Za brezposelne je gotovo najmanj primerno, da so šola, sedež izvajalca učne pomoči in njegovo bivališče zelo oddaljeni. 


\section{Kako različni subjekti sodelujejo pri izpeljavi učne pomoči?}

Glede na ugotovitve, da razporejenost (mreža) učne pomoči ni bila najboljša, se nam zdi kakovost stikov, ki jih imajo med seboj šole, izvajalci učne pomoči in zavodi za zaposlovanje, še posebej pomembna. Če so ti dobri in se vloge posameznih subjektov dopolnjujejo, je mogoče odpraviti marsikatero pomanjkljivost.

Večina šol (88 odstotkov) meni, da so dobile od zavodov za zaposlovanje dovolj natančne informacije o tem, da je organizirana učna pomoč. Večina šol je bila tudi zadovoljna s temi informacijami in le 17 odstotkov šol si želi dodatnih informacij.

Še bolj kot to nas je zanimalo sodelovanje med šolami in izvajalci učne pomoči. Povedati moramo, da smo kar s precejšnjo skepso ocenjevali dejstvo, da učna pomoč poteka zunaj šol, ker smo predvidevali, da ne bomo imeli dovolj kakovostnih informacij o tem, kakšno pomoč pravzaprav brezposelni potrebujejo, še posebej, če je učna pomoč potekala v drugem kraju, in ne tam, kjer se je brezposelni šolal. Tako smo povprašali, o čem šole obveščajo izvajalce učne pomoči. Dobili smo zanimive rezultate, ki se med seboj pomembno razlikujejo.

\begin{tabular}{|c|c|c|c|c|}
\hline \multicolumn{5}{|c|}{ Preglednier l O cem sole obveš́cajo izvajalce uóne pomó̀ } \\
\hline \multirow[t]{3}{*}{ O cem sole obvešccjo izvajake vine pomori? } & \multicolumn{2}{|c|}{ Ravnatelfisol } & \multicolumn{2}{|c|}{$\begin{array}{l}\text { Direktorilingialcev } \\
\text { utne ponoî }\end{array}$} \\
\hline & & $\%$ & Stevilo & $\%$ \\
\hline & & $100 \%=24$ & odgovorov & $100 \%=17$ \\
\hline \multicolumn{5}{|l|}{ Na kaletih predmetnih podrotith } \\
\hline je uťna pomoi najpotrebnejśs? & 14 & 50 & 6 & 35 \\
\hline Kakśsi so uéninoètit? & 11 & 46 & ? & 12 \\
\hline Kateri udelè̌enci so polrebri uéne ponoê? & 10 & 42 & 3 & 28 \\
\hline Na koge noi se obrocajo zo stike z vani? & 9 & 37 & 5 & 29 \\
\hline Kakšne ứne režave imajo udeleženci? & 9 & 37 & 1. & 6 \\
\hline Koleri vébeniki so predpisani pri posameznih predmetih? & 9 & 37 & 4 & 23 \\
\hline Kdaj so predvideno ocenjevenja, izpiti? & 9 & 37 & 2 & 12 \\
\hline Kakšni so posameznikoviuspehi? & 8 & 33 & 1. & 6 \\
\hline Stemiorganizacijami nimamo stikov. & 5 & 21 & 4 & 23 \\
\hline Drugo. & 4 & 17 & 4 & 23 \\
\hline
\end{tabular}

Kaže, da je obveščanje pomanjkljivo, saj le manjši delež šol obvešča izvajalce učne pomoči o problematiki s posameznih učnih področij. Mentorji in direktorji najpogosteje sodelujejo z osebami, ki so na šolah odgovorne za izobraževanje odraslih, na drugem mestu po pogostosti pa so stiki s predmetnimi učitelji in z ravnatelji šol. O tem, ali so se kdaj srečali z učitelji šol, kjer se izobražujejo udeleženci učne pomoči, je 35 odstotkov mentorjev odgovorilo, da ne, 65 odstotkov pa se jih je srečalo z učitelji.

Glede odnosov in stikov s šolami so najbolj kritični direktorji izvajalcev učne pomoči, skoraj polovica jih meni, da so bili ti zadovoljivi, slaba tretjina, da so bili dobri, 19 odstotkov je mnenja, da so slabi, in le 7 odstotkov, da so zelo dobri. Šole so v svojih ocenah manj kritične, če izvzamemo, da 21 odstotkov odgovorov kaže, da sploh nimajo stikov, 58 odstotkov šol meni, da so stiki dobri ali zelo dobri. Da so stiki slabi, ni omenila niti ena šola.

Za odgovore vseh skupin anketirancev je značilno sporočilo, da je premalo medsebojnega sodelovanja izvajalcev učne pomoči in šol, da je to slabo ali celo, da ga ni. Tu se kaže tudi premalo spodbujanja in usmerjanja, skratka premalo dejavna vloga zavodov za zaposlovanje in pri navezovanju stikov med šolami ter izvajalci učne pomoči. Stiki izvajalcev, direktorjev in mentorjev z zavodi za zaposlovanje sicer povsod obstajajo, vendar so predvsem administrativni, formalni. Izboljšanje sodelovanja med šolami in izvajalci učne pomoči, dejavnejša vloga zavodov za zaposlovanje sta nujen ukrep, ki ne zahteva dodatnega denarja, lahko pa bistveno izboljša delo. Doseči je treba predvsem sodelovanje med profesorji in mentorji, pa tudi institucionalne stike med šolami in izvajalci učne pomoči. Vloga zavodov za zaposlovanje pri obveščanju, navezovanju stikov, koordinaciji in zlasti pri nadzoru je najbrž jasna, le uresničiti jo je treba. 


\section{Slika 2: Ocena medsebojnih stikov direkłorjev in mentorjev s šolami fer ocene šol o stikih z izvajalci učne pomoči}

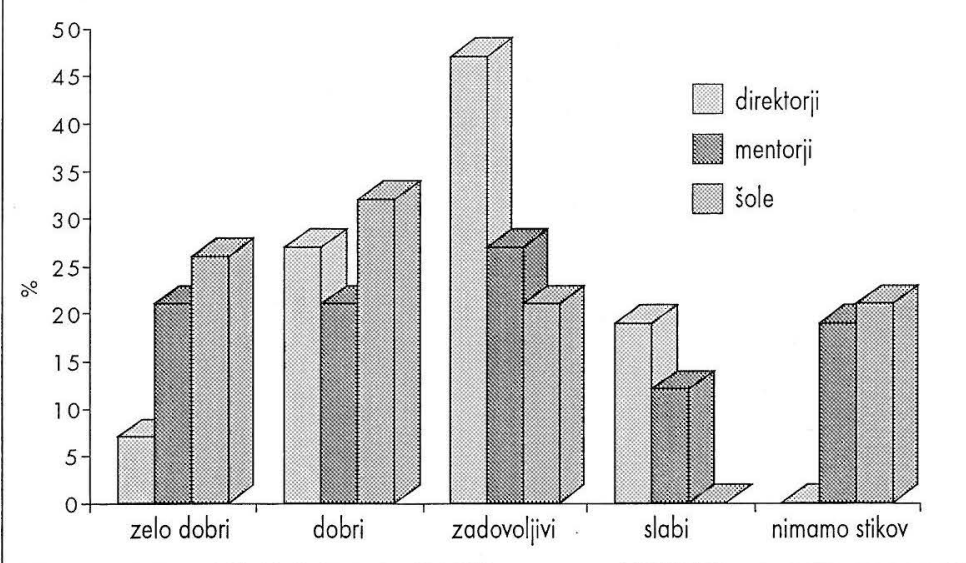

akademijo. Sedem mentorjev ali 13 odstotkov jih ima srednješolsko izobrazbo: gimnazijo, pedagoško gimnazijo, kemijsko, elektrotehniško, ekonomsko šolo, večina med njimi pa tudi še nedokončano višjo ali visoko šolo. Na vprašanje, kakšno delo so opravljali pred vključitvijo $\mathrm{v}$ učno pomoč, smo dobili tele odgovore: učitelj osnovne šole (9 odgovorov)), učitelj - profesor srednje šole (6), uvoz-

\section{Kdo so mentorjị, ki zagotavljajo učno pomoč?}

Mentorje smo povprašali o njihovi starosti, kakšno šolo so končali, skratka, kakšno izobrazbo imajo, kakšno delo so opravljali, preden so začeli sodelovati pri učni pomoči, ali so sploh že bili zaposleni in koliko časa so bili brezposelni, preden so postali mentorji. Najzanimivejši so seveda podatki o izobrazbi mentorjev.

\begin{tabular}{|c|c|}
\hline Stoprig inobratbe & Ougovoril y ods oilkit \\
\hline srednjesolka & 13 \\
\hline visjesolsica & 25 \\
\hline Visolcosolska & 32 \\
\hline Skopei & 1.90 \\
\hline
\end{tabular}

Med mentorji prevladuje visokošolska izobrazba, takih je 62 odstotkov, to je 32 mentorjev. Navajajo, da so končali strojno, pravno, ekonomsko, pedagoško, filozofsko fakuteto, likovno akademijo, geodezijo, biologijo, živilsko tehnologijo, fakulteto za družbene vede, fakulteto za naravoslovje, kmetijstvo, pomorstvo in promet. Trinajst mentorjev ali 25 odstotkov jih ima višješolsko izobrazbo in so končali višjo ekonomsko šolo, lesarstvo, višjo tehniško šolo, višjo upravno šolo, pedagoško izvoz in komerciala (4), profesor ekonomskih predmetov, delo v knjižnici (javna dela), direktor marketinga, profesorica geodezije, knjižničarka, tajnica, modni oblikovalec, vodja kontrole kakovosti, tehnolog, bančna uslužbenka, vodja poslovne enote, marketing, zastopstvo, pomočnik direktorja, poslovodja, direktor d. o. o.

Večina, to je 81 odstotkov kandidatov, je že imela izkušnje s poučevanjem, preden so postali mentorji. Malo izkušenj so imeli najmlajši mentorji, le dva ali tri mesece. Štirje mentorji so imeli do enega leta izkušenj, po dve leti tudi štirje, dva mentorja po tri leta in štirje po štiri leta. Starejši, že prej zaposleni v izobraževanju, so imeli po 8,12 in 23 let izkušenj s poučevanjem. Le 19 odstotkov mentorjev je bilo brez njih, ti pa so mladi in niso bili (dalj časa) brezposelni. Izkušnje s poučevanjem so opisali takole (v oklepaju je pri pogostejših odgovorih navedeno njihovo število): inštrukcije (15), učenje v osnovni šoli (10), poučevanje na srednji šoli (8), predavanje na LU za izobraževanje ob delu (3), poučevanje na jezikovnih šolah (4), nadomeščanje na osnovnih šolah (2), popoldansko varstvo in podaljšano bivanje (2), pripravništvo in obvezna pedagoška praksa (več odgovorov), vodenje različnih tečajev in seminarjev 
(4), poučevanje beguncev, mentorstvo pripravnikom.

Čeprav ti podatki nekoliko izboljšujejo podobo izbranih mentorjev in njihove (ne)usposobljenosti za mentorsko delo, nas je zanimalo, ali so izvajalske organizacije lahko izbirale med kandidati za mentorje ter koliko izobrazba mentorjev ustreza potrebam brezposelnih, ki se izobražujejo. Odgovori o možnostih izbire se razlikujejo po posameznih območjih. Manj kot polovica direktorjev izvajalcev učne pomoči (41 odstotkov) je v celoti vplivala na izbiro kandidatov. Zato ni čudno, da so mnenja direktorjev o ustreznosti izobrazbe mentorjev kritična. Težave $\mathrm{z}$ izobrazbo so večje tam, kjer imajo le enega ali dva mentorja, potrebe po učni pomoči pa se kažejo pri več predmetih (matematika, ekonomski predmeti, tuji jeziki, slovenščina, računalništvo ...). Res je tudi, da je bilo težav in slabšega sodelovanja z zavodi za zaposlovanje očitno več na začetku projekta, pozneje pa se je možnost vplivanja izvajalcev na izbiro mentorjev povečala.

V skladu z načrtom projekta učne pomoči naj bi se vsi mentorji pred začetkom dela udeležili uvodnega pedagoško-andragoškega usposabljanja. Direktorjem in mentorjem smo postavili dve vprašanji o tem usposabljanju.

\begin{tabular}{|c|c|c|c|c|}
\hline \multicolumn{5}{|c|}{ Preglednica 3. Usposabjjanje mentorjev - odgovori direkdoriev in mentorjev } \\
\hline \multirow{2}{*}{$\begin{array}{l}\text { Alje bilo uvodno } \\
\text { usposoblianie mentoriey } \\
\text { tadostno? }\end{array}$} & \multicolumn{2}{|c|}{$\begin{array}{l}\text { Odgovori } \\
\text { vvodstolkh) }\end{array}$} & \multirow{2}{*}{$\begin{array}{l}\text { Alibibilo potrebno } \\
\text { se kakśno uspossablanje } \\
\text { mentrier? }\end{array}$} & \multirow{2}{*}{$\begin{array}{l}\text { Odgovori } \\
\text { Jvodstorkhth }\end{array}$} \\
\hline & direkioni & mentori & & \\
\hline da & 0.47 & 10 & da & 0.0 .65 \\
\hline \multirow[t]{2}{*}{ ne } & 53 & 21 & he & 4.4 \\
\hline & 100 & 100 & & 109 \\
\hline
\end{tabular}

Glede usposobljenosti mentorjev se torej kažeta dve težavi: prva težava sta (neustrezna) strokovna izobrazba in obvladovanje učne snovi, zlasti v zahtevnejših programih, druga pa pomanjkljiva andragoška usposobljenost ali celo neusposobljenost. Sočasno pa je težava tudi $\mathrm{v}$ tem, da so kot brezposelni lahko $\mathrm{v}$ sklopu javnih del zaposleni le eno leto, nato ali že prej pa naj bi iskali zaposlitev drugje. To pomeni nenehno menjavanje mentorjev ter vpeljevanje in usposabljanje novih. Na podlagi mnenj vseh štirih skupin anketirancev lahko povzamemo, da ne zanikajo možnosti, da bi mentorstvo še naprej opravljali brezposelni, vendar je treba urediti njihov status in usposobljenost.

\section{Delovne razmere za učno pomoč}

Ustrezne delovne razmere, prostori, osnovna učna oprema in učno gradivo, delovni položaj, obseg dela in razporeditev delovnega časa so pomemben pogoj za uspešno izpeljavo učne pomoči in kakovost mentorjevega dela. Navedli bomo samo podatke o učnem gradivu, ki se nam zdijo najpomembnejši.

\begin{tabular}{|c|c|c|}
\hline \multicolumn{3}{|c|}{ 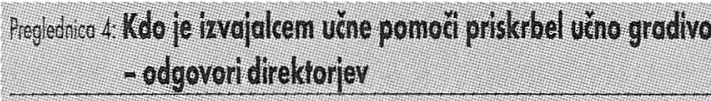 } \\
\hline Piskibele so ga sole & Semi so si ga piskibeli & Goninajo \\
\hline L Sterto odgovorov & L CStenlo odgovatox & Stevilo odgovers \\
\hline Uininatiti & (1) $=19$ & \\
\hline Ubentil & 14 & \\
\hline Pirocinle & 16 & 0 \\
\hline Slovari & 11 & 0 \\
\hline Prosolitice & 10 & \\
\hline Drugo & 6 & 0 \\
\hline
\end{tabular}

Odgovori mentorjev na vprašanje, ali imajo potrebno učno gradivo, in tudi odgovori direktorjev kažejo, da je pri učni pomoči to problem. Mentorji so še najbolje oskrbljeni z učbeniki (78 odstotkov), priročniki (59 odstotkov) in slovarji (53 odstotkov), učne načrte jih ima le 43 odstotkov, 9 mentorjev (18 odstotkov) je navedlo, da sploh nimajo potrebnega učnega gradiva.

\section{Kdo so iskalci učne pomoči?}

Po podatkih zavodov za zaposlovanje naj bi v letu 1999 uporabilo učno pomoč 3.015 brezposelnih, ki so bili vključeni v ponovno izobraževanje. Dejansko število tistih, ki so bili deležni učne pomoči, pa je verjetno manjše. 
Skupno število brezposelnih, ki so jih navajali izvajalci učne pomoči, je bilo 1.546. Pet izvajalcev ni odgovorilo. Dejstvo pa je, da ob uvedbi učne pomoči načrtovalci niso zagotovili enotnega načina spremljanja poteka, zato ni nekaterih temeljnih objektivnih podatkov. Sicer lahko sklepamo, da je do te razlike prišlo zato, ker so ponekod spremljali realizirane učne ure (posamezen brezposelni je prejemal pomoč pri več predmetih), vsekakor pa tako veliko neskladje zahteva čimprejšnje ureditev obvezne dokumentacije. Pri določanju vzorca smo sicer izhajali iz podatkov ZRSZ, torej iz večjega števila, kot je verjetno dejansko bilo.

Brezposelne udeležence izobraževanja smo prosili za podatke o njihovi starosti, izobrazbi ali končanem šolanju, zaposlenosti pred vključitvijo izobraževanje in delovni dobi. Anketirani brezposelni so stari od 15 do 48 let, približno polovica ali 49 odstotkov jih je starih do 25 let, druga polovica pa je starejša.

\begin{tabular}{|c|c|}
\hline \multicolumn{2}{|c|}{ Pregtedric 5: Storost brezposelnih, vklüenih v ứno pomó̀ } \\
\hline Starost & Odgovori (v odstotkih) \\
\hline do 20 & 2 \\
\hline $21 \mathrm{do} 25$ & 28 \\
\hline $26 \mathrm{do} 30$ & 19 \\
\hline 31 do 35 & 14 \\
\hline 36 do 40 & 10 \\
\hline $\operatorname{ned} 40$ & 8 \\
\hline skupdi & 100 \\
\hline
\end{tabular}

Prevladujejo brezposelni, ki so končali osnovno šolo (48 odstotkov). Poklicno šolo jih ima, po odgovorih sodeč, 40 odstotkov, vendar je ta podatek manj zanesljiv, ker so se nekateri priučili ali pa navajajo zgolj poklic (za katerega je sicer potrebna poklicna šola, a niso navedli, ali so jo res končali), zato je verjetno brezposelnih s končano osnovno šolo več kot polovica. Srednjo šolo jih je končalo 9 odstotkov, 5 odstotkov ali nekaj manj kot 3 odstotke jih ni dokončalo osnovne šole. Vsi ti podatki so torej povsem ujemajo s tistim, kar smo navedli v uvodu.

\section{Slika 3: Izobrazba brezposelnih, vključenih v učno pomoč}

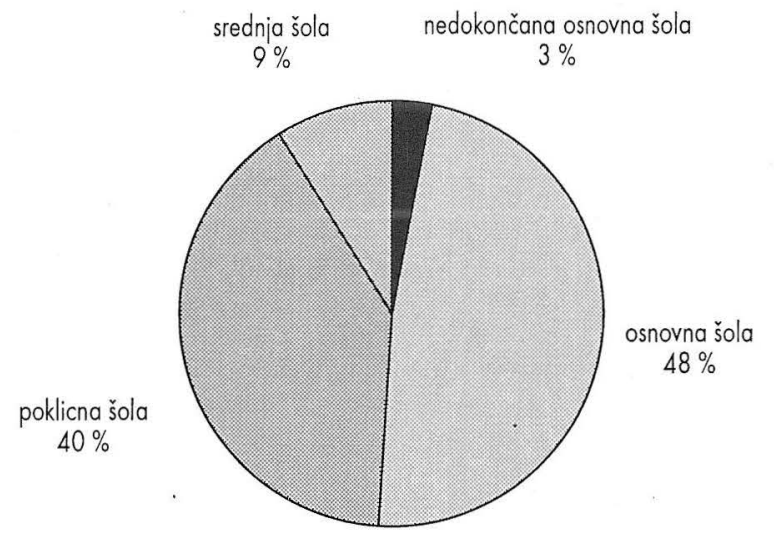

\section{Težave brezposelnih pri ponovnem vključevanju v izobraževanje}

Vprašanje o vzrokih nedvomno kar velikih težav brezposelnih pri ponovnem vključevanju v izobraževanje je bilo na vseh štirih vprašalnikih, nanj je bilo mogoče dati več odgovorov.

\begin{tabular}{|c|c|c|c|c|c|c|c|c|}
\hline \multirow{2}{*}{ liroklezor } & \multicolumn{2}{|c|}{$\begin{array}{l}\text { Odgovoridirektojey } \\
100 \%=17\end{array}$} & \multicolumn{2}{|c|}{$\begin{array}{l}\text { Odgovorinentoriey } \\
100 \%=51 \\
\text { stenilo yodstolkh }\end{array}$} & \multicolumn{2}{|c|}{$\begin{array}{l}\text { Odgovorisol } \\
100 \%=25 \\
\text { ślevilo vodslotkh }\end{array}$} & \multicolumn{2}{|c|}{$\begin{array}{l}\text { Odg. brezposelnih } \\
100 \%=100 \\
\text { Stevilov odstolkh }\end{array}$} \\
\hline & 16 & 94 & 40 & 88 & 20 & 80 & 4 & 25 \\
\hline \multicolumn{9}{|l|}{ odzadnjega solanja } \\
\hline slabe vene navode & 13 & 76 & 34 & 65 & 21 & 84 & 32 & 27 \\
\hline nepoznavanje u'crih metod & 9 & $9 \%$ & 24 & 46 & 7 & 20 & 3: & 16 \\
\hline drugo & 2 & 12 & 0 & 20 & 5 & 20 & 24 & 18 \\
\hline nezaninonje zo izobraževo & anje 1 & 6 & 11 & 21 & 7 & 28 & 4 & 2 \\
\hline
\end{tabular}

Mnenja vseh skupin anketirancev so precej enotna: največja težava pri ponovnem vključevanju v izobraževanje je slabo poprejšnje znanje in to, da je od zadnjega rednega šolanja minilo precej časa. Po pogostosti sledijo odgovori, da imajo brezposelni slabe učne navade in da ne poznajo učnih metod. Nezanimanje za izobraževanje so brezposelni za- 
nikali, vendar ga kot vzrok navaja 21 odstotkov mentorjev in 28 odstotkov šol.

Brezposelni potrebujejo pri ponovnem vključevanju v izobraževanje predvsem takšno pomoč, ki jim pomaga premagovati težave, ki smo jih navedli. To pa so razlaga posameznih delov učne snovi, ki ji pri pouku ne sledijo, in vaje; tu je delež odgovorov brezposelnih in mentorjev največji. Velik je tudi delež odgovorov, ki kaže, da potrebujejo mnogi brezposelni poleg neposredne učne pomoči zlasti spodbudo.

\begin{tabular}{|c|c|c|c|c|}
\hline \multicolumn{5}{|c|}{$\begin{array}{l}\text { Pregledtico } 7 . \text { Kokšno pomoc nq bolif polrebujejo brezposelni - odgovori brezposelnith } \\
\text { in mentorier }\end{array}$} \\
\hline \multirow[t]{3}{*}{ Visto pomoä } & \multirow{2}{*}{\multicolumn{2}{|c|}{$\begin{array}{c}\text { Odgovoribrezposelh } \\
\qquad 100 \%=191\end{array}$}} & \multirow{2}{*}{\multicolumn{2}{|c|}{$\begin{array}{l}\text { Odgovorimentojev } \\
100 \% \%=52\end{array}$}} \\
\hline & & & & \\
\hline & stevilo & $\%$ & Stevilo & $\%$ \\
\hline razlaga delov uéne snovi in solskega prograna & -137 & 68 & a. 48 & 92 \\
\hline 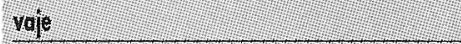 & 129 & 67 & 47 & 90 \\
\hline spodbuda & 60 & 31 & 39 & 75 \\
\hline ponovlan'e snoviziznizith lehikov izobroievania & 83 & 29 & 38 & 73 \\
\hline nepolki, kekle se uelit : - - - & 3! & H & 32 & 612 \\
\hline drugo & 3 & 2 & & 2 \\
\hline
\end{tabular}

Od pomoči, ki jo mentorji dajejo brezposelnim, so na prvem mestu individualne inštrukcije iz učne snovi, na drugem mestu pa je spodbujanje. To dokazuje, da je motiviranje pomembna vloga učne pomoči, pred izboljševanjem učnih navad, navajanjem na učne metode in skupinskim dopolnilnim poukom. Za-

Pomemben dejarnik učne moč je motiviranje za učenje. nimivo je, da so odgovori iz vseh treh vprašalnikov razvrščeni (rangirani) enako (vprašanja $\mathrm{v}$ vprašalniku so bila $\mathrm{v}$ drugačnem vrstnem redu), da so torej mnenja o oblikah pomoči, ki jo brezposelni potrebujejo, identična. Opazna pa je razlika pri oceni pomembnosti posamezne oblike pomoči, kakor jih navajajo posamezni respondenti, iz česar je mogoče tudi sklepati, da gre za različen pomen, ki ga posamezna vrsta respondentov pripisuje različnim obli- kam učne pomoči. Tako na primer manj kot tretjina brezposelnih meni, da potrebujejo ponavljanje iz nižjih letnikov njihovega izobraževanja, oziroma tri četrtine mentorjev. Prav tako imajo brezposelni o sebi dobro mnenje, da se znajo učiti, medtem ko skoraj dve tretjini mentorjev menita, da brezposelni potrebujejo napotke, kako se učiti.

Predmeti, pri katerih je največ povpraševanja po učni pomoči, so: matematika oziroma poslovna in finančna matematika, tuji jezik prevladuje angleščina, sledi nemščina, slovenščina, kemija, fizika, drugi predmeti: računovodstvo, računalništvo, blagoznanstvo, matematične metode, poslovna informatika, statistika, gospodarsko poslovanje, strojni elementi, biologija, italijanščina, naravoslovje. Ugotavljamo, da je največ težav pri splošnih predmetih. Najverjetneje zato, ker je poprejšnje znanje udeležencev slabo ali zastarelo in ker so imeli z njimi težave že med prejšnjim šolanjem. Večje težave pri strokovnih predmetih se bodo nemara pojavile $\mathrm{v}$ višjih letnikih, vendar je vprašanje, ali bodo izvajalci učne pomoči lahko našli usposobljene mentorje v sklopu javnih del.

\section{OCENA USPEŠNOSTI UČNE POMOČI}

Zanimalo nas je, ali je učna pomoč pomagala izboljšati učni uspeh brezposelnim udeležencem izobraževanja, kako so zadovoljni z mentorji in kako na splošno ocenjujejo tako pomoč. Sodeč po odgovorih, je kar 99 odstotkom vprašanim učna pomoč pomagala izboljšati učni uspeh, kar 91 odstotkov pa jih je zelo zadovoljnih z mentorji.

Od vseh štirih skupin anketirancev smo želeli dobiti mnenje, kako na splošno ocenjujejo projekt učne pomoči. Najbolje so projekt ocenili brezposelni, 84 odstotkov jih meni, da je odličen ali zelo dober. Med mentorji in direktorji izvajalcev UP jih 75 odstotkov meni, da 


\section{Slika 4: Ali vam je učna pomoč pomagala izboliǰsati uspeh - odgovori brezposelnih}

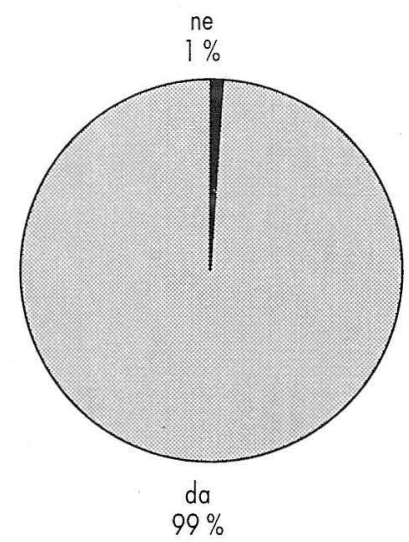

je zelo dober ali odličen. Pri šolah prevladuje z 38 odstotki ocena, da je dober, 29 odstotkov šol meni, da je zelo dober, in 23 odstotkov, da je le zadovoljiv.

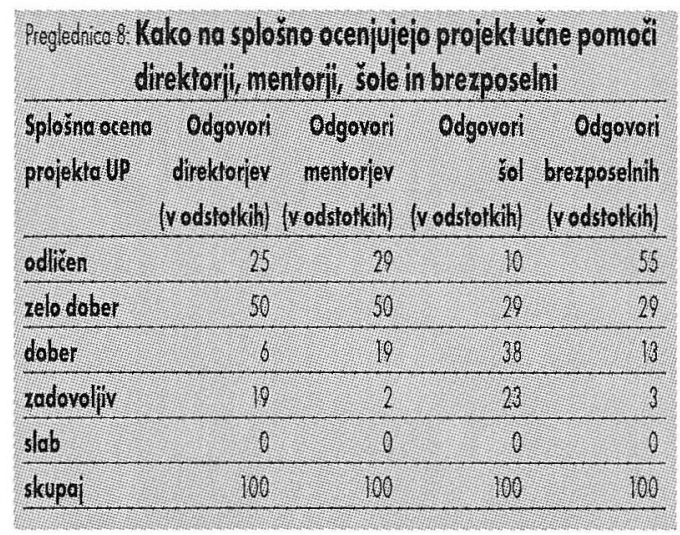

Čeprav so bile v dozdajšnjih odgovorih kritično ocenjene začetne težave, posamezni dejavniki, prijemi in vsebine, pa se za nadaljevanje projekta zavzema velika večina izvajalcev UP, direktorjev in mentorjev ter šol.

Vsem štirim skupinam anketirancev smo postavili tudi tri enaka vprašanja, in sicer katere so prednosti projekta učne pomoči, katere so po njihovem mnenju njegove kritične točke ali slabosti in kaj predlagajo za njegovo izboljšanje.

Glede prednosti projekta so si mnenja prese-
Slika 5: Ali kaže projekt učne pomoči nadaljevati - odgovori direkłorjev, mentorjev in šol

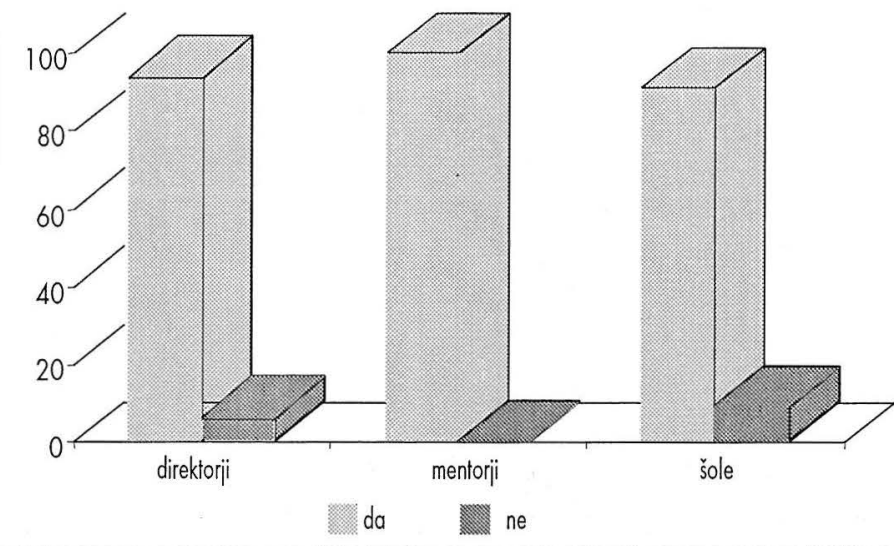

netljivo podobna. Prednosti bi lahko strnili v tri temeljne skupine: 1 . boljši učni uspehi udeležencev in prilagajanje potrebam brezposelnih; 2. premagovanje subjektivnih težav in motiviranje brezposelnih; 3 . brezplačnost.

Sklepno mnenje raziskave o učni pomoči brezposelnim je mogoče strniti takole: projekt učne pomoči bi se moral nadaljevati in razširiti; pomoč je treba dati vsem brezposelnim, ne le brezposelnim iz Programa 5000, celo vsem odraslim udeležencem izobraževanja, zaposlenim in brezposelnim; zamisel o učni pomoči naj bi preverili tudi za mlade, $z$ delno denarno pomočjo; povečati je treba število mentorjev, tako da bo učna pomoč dostopna vsem, ki jo potrebujejo, da bodo lahko dobili več ur in da bo bolj prilagojena času, ki ga imajo na voljo udeleženci izobraževanja.

Tako kot za prednosti velja tudi za oceno slabosti ugotovitev, da so o nekaterih premalo določenih ali tudi neurejenih zadevah (status mentorjev, opredelitev učne pomoči, sodelovanje med šolami, izvajalci učne pomoči in zavodi za zaposlovanje) mnenja šol, direktorjev, mentorjev in tudi brezposelnih podobno kritična. Strnili smo jih v štiri skupine: 1 . začetna slaba pripravljenost projekta; 2 . neurejen status in (ne)usposobljenost mentorjev; 3. premalo sodelovanja in stikov med vsemi, 


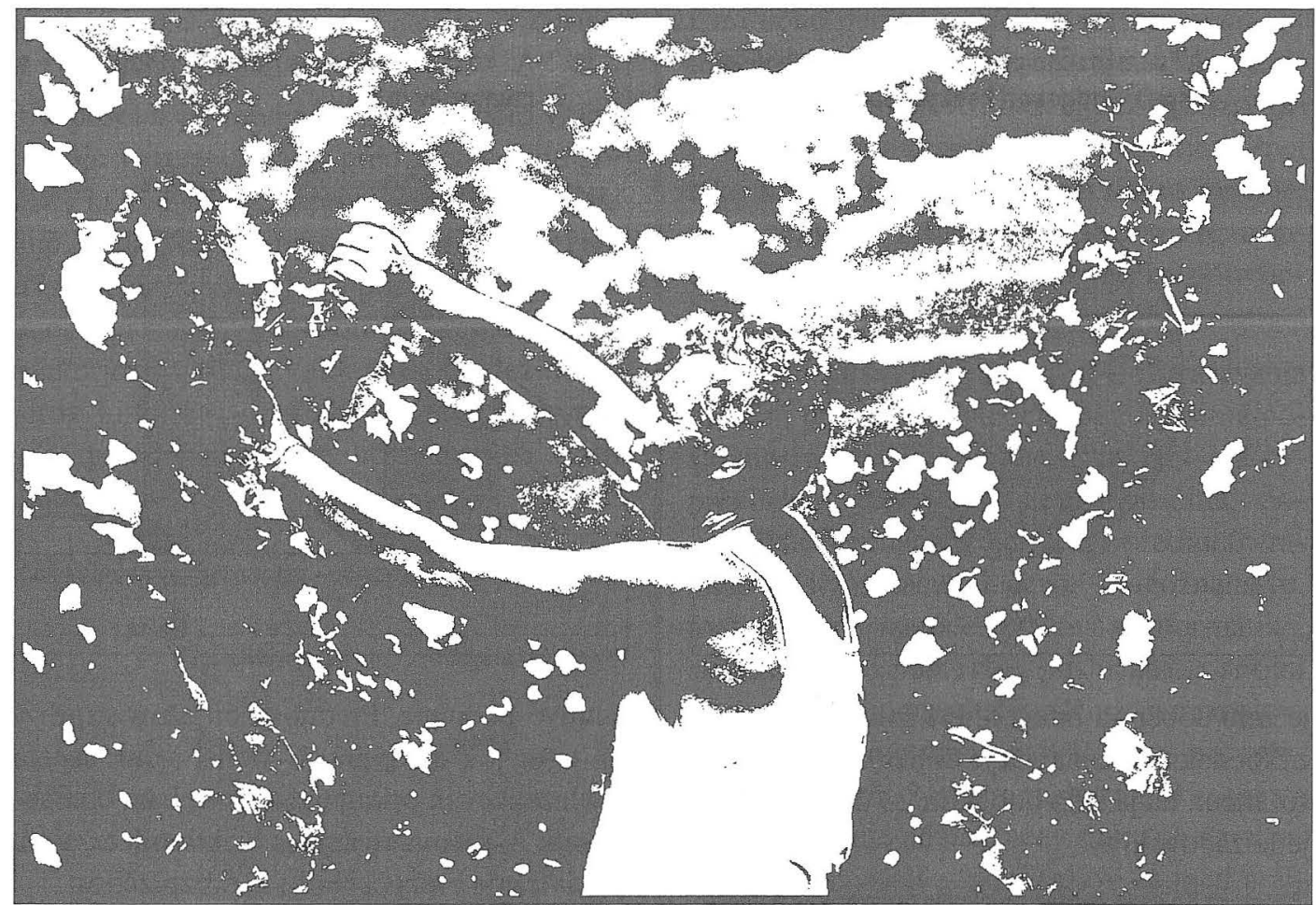

ki sodelujejo pri projektu; 4. neobveščenost in/ali nezanimanje udeležencev izobraževanja.

\section{SKLEPNE MISLI}

Na koncu je mogoče ugotoviti, da je Program 5000 nedvomno »prinesel« nekaj, česar vsaj $\mathrm{v}$ tako organizirani obliki v slovenskem sre-

Lokalna oddaljenost izobraževanja in usposobljenost mentorjev sta dva najpomembnejša elementa učne pomoči. dnješolskem izobraževanju odraslih nismo poznali - to je individualno pomoč posamezniku, da bi lahko premagal ovire pri ponovnem vključevanju v izobraževanje. To je še toliko bolj razveseljivo zato, ker si nekateri andragogi že dolga leta prizadevajo, da bi se tudi v izobraževanju odraslih uveljavile svetovalne službe, ki bi med drugim imele deloma tudi vlogo, ki jo ima opisana učna pomoč, zlasti v zvezi s tistim delom, ki se nanaša na razvija- nje motivacijskih dejavnikov, odpravljanje ovir in pomoč pri učnih težavah. Žal je strokovno prizadevanje doslej vedno zavrlo pojasnjevanje šolskih oblasti, da za svetovalno delo v izobraževanju odraslih ni dovolj denarja. Morda pa bo prav potreba, ki jo narekujejo cilji Programa 5000, vplivala na to, da se bo odnos do tega vprašanja spremenil, še posebej, ker je ideja očitno naletela na zelo ugoden odmev ne samo pri uporabnikih, ampak tudi v šolski praksi.

Očitno je tudi, da je bila sama zamisel o učni pomoči dokaj dobro izpeljana, če upoštevamo, da je nastala že po začetku šolskega leta in je bila izpeljana še v istem letu. Vsekakor pa sama izpeljava zahteva še nekatere korenite razmisleke in hkrati tudi drugačno ravnanje. Opozorili bi na dve po našem mnenju temeljni vprašanji. Prvo vprašanje je vprašanje razmestitve učne pomoči, ki ni enaka razmestitvi šolanja ali bivanja brezposelnih oseb. V izobraževanju odraslih poznamo raziskave, ki 
so nedvomno dokazale, da na motivacijo in učinkovitost učenja odraslih zelo vplivajo situacijske ovire, med katere prav gotovo spada lokalna oddaljenost izobraževanja. Enako velja seveda tudi za učno pomoč in ni čudno, da so šole in izvajalci učne pomoči opozarjali, da brezposelni ne »koristijo《 možnosti, ki so jim na voljo. To vprašanje - vprašanje lokalne oddaljenosti šolanja in učne pomoči - negativno vpliva tudi na kakovostno povezovanje učiteljev in mentorjev pri ugotavljanju posameznikovih težav in dogovarjarjanju o strategijah njihovega odpravljanja. Drugo temeljno vprašanje pa je vprašanje mentorjev. Če bi želeli, da bi učna pomoč odraslim postala kakovostni dejavnik tega izobraževanja, ni mogoče problema reševati z nekaj brezposelnimi, ki sicer imajo razmeroma ustrezno stopnjo izobrazbe, a prav gotovo premalo andragoškega znanja. Tega jim ni mogoče »dati« na kratkem seminarju, nato pa po določenem času (po preteku statusa javnega dela) mentorje nadomestiti z novimi, prav tako pomankljivo usposobljenimi, jih zopet usposabljati itd. To je $v$ nasprotju $\mathrm{z}$ vsako zdravo in razumsko logiko. Vlaganje $\mathrm{v}$ znanje mentorjev $\mathrm{z}$ vidika nacionalnega projekta je popolnoma neekonomično, saj delo mentorjev opravljajo le kratek čas po usposobljanju. Tisti, ki odločajo o javnih delih, pojasnjujejo, da ni cilj javnega dela to, da bi nekdo dolga leta ostal $» j a v n i$ delavec«, temveč to, da se ga čimprej zaposli. To je načeloma mogoče razumeti, ni pa mogoče razumeti, kakšen smisel ima iskati mentorje med ljudmi, za katere vnaprej vemo, da bodo to delo lahko opravljali le kratek čas, čeprav bodo pri delu zelo uspešni in bi radi opravljali to delo. Za tako ravnanje sicer obstajajo pojasnila, toda to so že birokratske zgodbe.

In čisto za konec: v šolskem letu 1999/2000 se je število izvajalcev učne pomoči in mentorjev zmanjšalo, zamenjanih je bilo precej mentorjev, niso nam znani podatki, da bi potekalo usposabljanje novih mentorjev ...

\section{LITERATURA}

Ivančič, Angelca (1999). Izobraževanje in priložnosti na trgu dela: izobraževanje, strukturne spremembe in mobilnost na trgu dela v obdobju 1974-1994 (zbirka Znanstvena knjižnica, 36). Ljubljana: Fakulteta za družbene vede: Andragoški center Republike Slovenije.

Izobraževanje brezposelnih (1993). Zbornik (Izobraževanje odraslih, Nove poti, 4). Ljubljana: Andragoški center Republike Slovenije.

Klemenčič, Sonja, Vilič - Klenovšek, Tanja (1995). Odpravljanje psihosocialnih posledic daljše brezposelnosti $\mathrm{z}$ izobraževanjem: andragoški pristop $\mathrm{k}$ pripravi izobraževalnega programa. V: Svetina, Metka (ur.). Zbornik prispevkov s posveta Vloga izobraževanja odraslih pri demokratizaciji družbe, Postojna, 1. in 2. decembra 1994. Ljubljana: Andragoško društvo Slovenije.

Mcgivney, Veronica (1992). Motivating Unemployed Adults to Undertake Education and Training. Leicester: The National Institute of Adult Education.

Program 5000. Program izobraževanja brezposelnih oseb v šolskem letu 1998/99. Poročilo (1999). Ljubljana: Zavod Republike Slovenije za zaposlovanje.

Rečnik, Metka (2000). Evalvacija učne pomoči brezposelnim. Ljubljana: Andragoški center Slovenije.

Skupina avtorjev (1993). Brezposelnost, izobraževanje in kariera (Izobraževanje odraslih, Nove poti, 5). Ljubljana: Andragoški center Republike Slovenije.

Svetlik, Ivan, Vilič - Klenovšek, Tanja, Klemenčič, Sonja, Hribar, Samo (1993). Izobraževanje in trg dela (Izobraževanje odraslih, Nove poti, 3). Ljubljana: Andragoški center Republike Slovenije.

Vilič - Klenovšek, Tanja (1998). Izobraževanje brezposelnih v letu 1997. Novičke, 1998/2. Ljubljana: Andragoški center Slovenije.

Vilič - Klenovšek, Tanja, Klemenčič, Sonja, Malečkar, Vilma, Černoša, Slavica, Svetina, Metka, Kožuh, Boris (1997). Evalvacija politike izobraževanja delovne sile s poudarkom na izobraževanju brezposelnih: raziskovalni projekt: zaključno poročilo. Del 2. Ljubljana: Andragoški center Republike Slovenije.

* Iz opravljene analize objavljamo samo tiste dele, ki so pretežno andragoške narave, izpustili pa smo precej tistega, kar se nanaša na organizacijo projekta. Analizo si je mogoče v celoti ogledati v knjižnici Andragoškega centra Slovenije. 